\title{
Considerations of Inheritance in Zdeněk Fibich's Symphonic Poems
}

\section{Patrick F. Devine}

The entry on the symphonic poem in the 1980 edition of The New Grove Dictionary of Music and Musicians ${ }^{1}$ begins naturally enough with sections entitled "Introduction", "Origins" and "Liszt". These lead directly to the fourth section, in which the focus is trained on "The Czech Lands", ahead of subsequent sections on Russia, France, Germany and other countries. This sequence highlights the important pioneering attempts of a number of composers in Bohemia and Moravia who contributed vitally to the evolution of a form which was barely out of its infancy.

This sudden flowering of activity in the new genre stood in sharp relief against a backdrop of virtual stagnation in the development of the Czech symphony during the middle of the nineteenth century; after all, there had been no significant representative work in the "canon" for some fifty years since the Symphony in D of 1821 by Jan Václav Voříšek (1791-1825), even though both Bedřich Smetana (1824-1884) with his Slavnostni symfonie [Festive Symphony] of 1854 and Antonín Dvořák (1841-1904) with his first two symphonies, both from 1865, had continued the central European symphonic tradition without any appreciable breakthrough or impact. Instead, Smetana's three "Swedish" symphonic poems of 1858-1861, i.e. Richard III, Valdštýnưv tábor [Wallenstein's Camp] and Hakon Jarl, achieved a certain notoriety and today stand as early landmarks in the history of the genre.

The twenty-two-year-old Zdeněk Fibich (1850-1900) turned to the fledgling form in 1873 with the first two of his works, Othello and Záboj, Slavoj a Luděk [Záboj, Slavoj and Luděk]; the other three pieces, Toman a lesni panna [Toman and the Wood Nymph], Bourre [The Tempest] and Vesna [Spring], followed in the next eight years. Illustration 1 presents a table of basic information about the five works:

1 Hugh Macdonald, "Symphonic poem”, The New Grove Dictionary of Music and Musicians, ed. Stanley Sadie (London: Macmillan, 1980), vol. 18, pp. 428-433. 
Illustration $1^{2}$

\begin{tabular}{|l|c|c|c|c|}
\hline Title & $\begin{array}{c}\text { Generic } \\
\text { description }\end{array}$ & $\begin{array}{c}\text { Catalogue and } \\
\text { opus numbers }\end{array}$ & $\begin{array}{c}\text { Initial } \\
\text { and final keys }\end{array}$ & Date \\
\hline Othello & symphonic poem & H177/op. 6 & D $\rightarrow$ D & 23-31/5/1873 \\
\hline $\begin{array}{l}\text { Záboj, Slavoj } \\
\text { a Luděk }\end{array}$ & symphonic poem & H179/op. 37 & $\mathrm{a} \rightarrow \mathrm{A}$ & 1873 \\
\hline $\begin{array}{l}\text { Toman } \\
\text { a lesní panna }\end{array}$ & $\begin{array}{c}\text { symphonic picture } \\
\text { Bouře }\end{array}$ & H197/op. 49 & $\mathrm{d} \rightarrow \mathrm{d}$ & $\begin{array}{c}3 / 7 / 1874- \\
22 / 2 / 1875\end{array}$ \\
\hline Vesna & $\begin{array}{c}\text { symphonic picture } \\
{[. . .]}\end{array}$ & H259/op. 46 & fluid $\rightarrow \mathrm{F}$ & $1 / 5 / 1880$ \\
\hline
\end{tabular}

Consequently these belong to the first half of his creative career, and although he had already tried his hand at plenty of abstract works including two symphonies (which have not survived), a concert piece and an orchestral fantasy ${ }^{3}$, his artistic sensibility may well have been the stimulus for him to consider the symphonic poem, or symphonic picture (in Czech symfonicky obraz) as he eventually preferred to call it.

It is not known to what extent Fibich would have been aware of the symphonic poems of both Franz Liszt (1811-1886) and Bedřich Smetana, but one presumes that he would have been at least somewhat familiar with the Czech composer's set of three from his time in Sweden. The aim of this paper is to identify those aspects in Fibich's works which are shared with his predecessors and those (if any) which represent a departure or novel ingredient in the music. There is a certain amount of overlapping as works were introduced to the world, and Illustration 2 charts a chronological list of first performances and, where it is known for an individual piece, the year of its publication:

2 Most of the details found here were taken from Vladimír Hudec, Zdeněk Fibich: Tematický katalog (Prague: Editio Bärenreiter, 2001); only the final keys were added by the author.

3 See Vladimír Hudec (as note 2), 108-109, 142-143, 138 and 202 respectively. 
Illustration $\mathbf{2}^{4}$

\begin{tabular}{|c|c|c|c|}
\hline \multicolumn{4}{|c|}{ Chronological list of first performances of symphonic poems } \\
\hline Date & Place & Composer & Work \\
\hline 28 August 1849 & Weimar & Liszt & $\begin{array}{l}\text { Tasso: lamento e trionfo } \\
\text { (in print 1856) }\end{array}$ \\
\hline February 1850 & Weimar & Liszt & $\begin{array}{l}\text { Ce qu'on entend sur la montagne } \\
\text { ('Bergsymphonie') (in print 1857) }\end{array}$ \\
\hline 24 August 1850 & Weimar & Liszt & Prometheus (in print 1856) \\
\hline 16 February 1854 & Weimar & Liszt & Orpheus (in print 1856) \\
\hline 28 February 1854 & Weimar & Liszt & Les préludes (in print 1856) \\
\hline 16 April 1854 & Weimar & Liszt & Mazeppa (in print 1856) \\
\hline 9 November 1854 & Weimar & Liszt & Festklänge (in print 1856) \\
\hline 8 September 1856 & Budapest & Liszt & Hungaria (in print 1857) \\
\hline 5 September 1857 & Weimar & Liszt & Die Ideale \\
\hline 10 November 1857 & Breslau & Liszt & Héroïde funèbre (in print 1857) \\
\hline 28 December 1857 & Weimar & Liszt & Hunnenschlacht \\
\hline 1 or 5 January 1862 & Prague & Smetana & Richard III \\
\hline 1 or 5 January 1862 & Prague & Smetana & $\begin{array}{l}\text { Valdštýnův tábor / } \\
\text { Wallenstein's Lager }\end{array}$ \\
\hline 24 February 1864 & Prague & Smetana & Hakon Jarl \\
\hline 7 December 1873 & Prague & Fibich & Othello \\
\hline 25/26 May 1874 & Prague & Fibich & Záboj, Slavoj a Luděk \\
\hline 14 March 1875 & Prague & Smetana & Vyšehrad \\
\hline 4 April 1875 & Prague & Smetana & Vltava \\
\hline 2 July 1876 & Sondershausen & Liszt & Hamlet \\
\hline 10 December 1876 & Prague & Smetana & Z českých luhů a hájů \\
\hline 17 March 1877 & Prague & Smetana & Šárka \\
\hline 24 March 1878 & Prague & Fibich & Toman a lesní panna \\
\hline 4 January 1880 & Prague & Smetana & Tábor \\
\hline 4 January 1880 & Prague & Smetana & Blanik \\
\hline 16 May 1880 & Prague & Fibich & Bouree \\
\hline 26 March 1881 & Prague & Fibich & Vesna \\
\hline
\end{tabular}

4 Information for this illustration was gathered from the following sources: Humphrey Searle, "Liszt, Franz", The New Grove Dictionary of Music and Musicians, ed. Stanley Sadie (London: Macmillan, 1980), vol. 11, pp. 28-74; John Clapham, "Smetana, Bedřich", The New Grove Dictionary of Music and Musicians, ed. Stanley Sadie (London: Macmillan, 1980), vol. 17, pp.391-408; Bedrich Smetana: Time, Life, Work (Prague: Bedřich Smetana Museum, 1998), 68-79 and 122-123; John Tyrrell, "Fibich, Zdeněk", The New Grove Dictionary of Music and Musicians (London: Macmillan, 1980), vol. 6, pp. 520-526; Vladimír Hudec (as note 2). 


\begin{tabular}{|l|l|l|l|}
\hline Chronological list of first performances of symphonic poems \\
\hline Date & Place & Composer & Work \\
\hline [5 November 1882 & Prague & Smetana & Má vlast] \\
\hline [27 February 1884 & St Petersburg & Liszt & Von der Wiege bis zum Grabe] \\
\hline
\end{tabular}

The only symphonic poem to appear after the completion of all of Fibich's five is the thirteenth and final member of Liszt's series, i.e. Von der Wiege bis zum Grabe, so that work may be eliminated from our inquiry into these pieces. We are left with a total of twenty-six compositions, with Liszt responsible for twelve, Smetana for nine and Fibich for five.

For his subject matter Fibich closely follows both Liszt and Smetana as he seeks inspiration in three areas of source-material: (i) Shakespearean drama, in Othello and Boure (compare with Liszt's Hamlet and Smetana's Richard III), (ii) poetry, in Záboj, Slavoj a Luděk and Toman a lesnípanna (compare with Liszt's Ce quion entend sur la montagne) and (iii) nature, in Vesna (compare with Liszt's Die Ideale and Smetana's Z českých lubì a hájü). As is well known, the Czech aesthetician, critic and librettist Otakar Hostinský (1847-1910) identified Záboj, Slavoj a Luděk as the first symphonic poem to be based on Czech material.

By definition the symphonic poem as a genre implies a relationship to the symphony, and in this context it is instructive to compare how Liszt and Fibich approached both forms. An identical strategy is used by Liszt in terms of changes in tempo, key-signature and metre - or any combination of these - when announcing a new theme; in this regard one need only compare the first movement of $A$ Faust Symphony with his seventh symphonic poem, Festklänge, as shown in Illustration 3: 
Illustration $3^{5}$

\begin{tabular}{|c|c|c|c|c|}
\hline \multicolumn{5}{|c|}{ Changes of tempo, key-signature and metre in Liszt's symphonic music } \\
\hline Work & Page/bar-number & New tempo & $\begin{array}{c}\text { New } \\
\text { key-signature }\end{array}$ & $\begin{array}{c}\text { New } \\
\text { time-signature }\end{array}$ \\
\hline $\begin{array}{c}\text { A Faust } \\
\text { Symphony, I }\end{array}$ & score, p. 35 & $\begin{array}{c}\text { Affettuoso } \\
\text { poco andante }\end{array}$ & 4\# (E) & $\begin{array}{c}\text { Alternating bars of 3/4 } \\
\text { and C }\end{array}$ \\
\hline & p. 59 & $\begin{array}{c}\text { Tempo I. } \\
\text { Allegro agitato assai }\end{array}$ & - (Eb implied) & C \\
\hline Festklänge & p. 20, b.116 90 & $\begin{array}{c}\text { Affettuoso, } \\
\text { poco andante } \\
\text { Allegretto } \\
\text { (Tempo rubato) }\end{array}$ & 4\# (E) & $\begin{array}{c}\text { Alternating bars of 3/4 } \\
\text { and C }\end{array}$ \\
\hline & p. 46, b. 307 & Andante sostenuto & 2\# (D) & 3/4 \\
\hline p. 81, b.552 & $\begin{array}{c}\text { Allegro mosso } \\
\text { con brio }\end{array}$ & - (C) & Cplit C \\
\hline
\end{tabular}

By contrast the first movement of Fibich's First Symphony contains no internal change of either key-signature or metre, only of tempo ${ }^{6}$, while there are four such composite adjustments in Othello, as demonstrated by Illustration 4, and one of these lasts a mere four bars:

\section{Illustration $\mathbf{4}^{7}$}

\begin{tabular}{|c|c|c|c|c|}
\hline \multicolumn{5}{|c|}{ Changes of tempo, key-signature and metre in Fibich's symphonic poems } \\
\hline Work & Page/bar-number & New tempo & $\begin{array}{c}\text { New } \\
\text { key-signature }\end{array}$ & $\begin{array}{c}\text { New } \\
\text { time-signature }\end{array}$ \\
\hline Othello & score, p. 20, b.107 & $\begin{array}{c}\text { Adagio ma } \\
\text { non troppo }\end{array}$ & $2 \mathrm{~b}(\mathrm{Bb})$ & $3 / 4$ \\
\hline & p. $46, \mathrm{~b} .249$ & $\begin{array}{c}\text { Allegro feroce } \\
\text { quasi presto }\end{array}$ & $1 \mathrm{~b}(\mathrm{~d})$ & split C \\
\hline $\begin{array}{c}\text { qdagio ma } \\
\text { non troppo }\end{array}$ & $2 \mathrm{~b}(\mathrm{Bb})$ & $3 / 4$ \\
\hline only!] & p. $75, \mathrm{f}, \mathrm{b} .4738$ & Allegro & $2 \#(D)$ & split C \\
\hline
\end{tabular}

A brief examination of the initial information provided by scores reveals on the one hand where Fibich adheres to the path taken by his two predecessors and

5 The scores used are as follows: Liszt: Eine Faust-Symphonie (London: Eulenburg, n.d.) and Liszt: Festklänge (London: Eulenburg, n.d.).

6 See Fibich: I. Symfonie F dur op.17 (Prague: SNKLHU, 1960), where the changes of tempo occur on pp. 15, 22, 29, 49, 52, 64, 66 and 69 of the score.

7 The score used is as follows: Fibich: Othello op.6 (Prague: SNKLHU, 1960). 
on the other where he strikes out on his own. This initial information consists of four fields: (i) initial tempo, (ii) initial key-signature, (iii) initial metre and (iv) orchestral forces used.

(i) Regarding initial tempo all three composers responded similarly, expressing a slight preference for speeds that are slower than allegro. However, while these served to establish slow introductory sections for Liszt ${ }^{8}$ and Smetana ${ }^{9}$, after Othello Fibich dispensed with them and in each subsequent work launched directly into the main movement.

(ii) In terms of opening keys Liszt (marginally) and Smetana (clearly) favour minor tonality over major ${ }^{10}$, while Fibich arrives at an even division in four of his settings ${ }^{11}$. The exception, Boure, sets out on a series of diminished seventh chords which keep a recognizable key at bay, and in this respect it mirrors the procedure adopted by Liszt at the start of his Prometheus and Smetana in Hakon Jarl.

(iii) Most of Liszt's pieces begin in either common or split common time ${ }^{12}$ and, as if in homage to the Hungarian composer, common time features in all three of Smetana's Swedish works. Thereafter, however, he employs a more varied palette of metres. Fibich retreats to common and split common time for three of his symphonic poems ${ }^{13}$.

(iv) The orchestral forces engaged by Fibich broadly resemble those used by his predecessors, i.e. double woodwind augmented by a piccolo, four horns, three trumpets, three trombones and tuba, timpani and two other percussion, and strings. He is fonder than Smetana of an additional (third) clarinet, and he is the first to include a fourth trumpet part, in Othello and Záboj, Slavoj a Luděk. While the harp, or even two harps, may make an occasional appearance in the symphonic poems of Liszt and Smetana ${ }^{14}$, Fibich adopts

8 Slow introductory sections open the following Liszt symphonic poems: Tasso, Les préludes, Orpheus, Héroïde funèbre, Hungaria, Hamlet and Die Ideale.

9 The following works by Smetana contain slow introductory sections: Richard III, Hakon Jarl, Vyšehrad, Z českých luhư a hájů and Tábor.

10 The following seven works by Liszt begin in a minor key: Tasso, Mazeppa, Héroïde funèbre, Hungaria, Hamlet, Hunnenschlacht and Die Ideale, the latter opening in C sharp minor despite a keysignature of one flat. Six of Smetana's symphonic poems share a minor-key start: Richard III, Vltava, Śárka, Z českých luhư a hájü, Tábor and Blaník.

11 Othello and Vesna begin in the major, Záboj, Slavoj a Ludék and Toman a lesni panna in the minor.

12 Common or split common time features at the start of the following Liszt works: Ce quion entend sur la montagne, Tasso, Les préludes, Orpheus, Prometheus, Festklänge, Héroïde funèbre, Hunnenschlacht and Die Ideale.

13 These are Othello, Záboj, Slavoj a Luděk and Bouře.

${ }_{14}$ The following compositions contain music for one or two harps: Ce quion entend sur la montagne, Les préludes and Orpheus by Liszt, and Richard III, Hakon Jarl, Vyšehrad and Vltava by Smetana. 
the instrument as a standard member and writes for it in all five of his works. As it happens the contemporary First Symphony also contains a harp part, but not his two later symphonies.

Solo openings reveal a gradual development, from those in the symphonic poems by Liszt when a theme may be presented by more than one instrumental line as in Tasso, Les préludes and Hunnenschlacht to the familiar beginning of Smetana's Vltava, where the number of prominent players is reduced to two but discreetly supported by a minimal accompaniment. In this regard the initial cadenza bar of Vyšehrad constitutes a genuine solo, although the elaborate music is shared between two harpists with independent parts. Fibich reduces the sonic amplitude still further to a single line of music when he scores the opening of Vesna for two clarinettists in unison without any accompaniment.

The most famous characteristic of the symphonic poem as established by Liszt, i.e. thematic transformation, is naturally exploited by all three composers. The familiar changes of speed, key and rhythm - and their various permutations - feature in all of this music, and by way of example Illustration 5 traces the course of Fibich's reworking of a principal theme in one of his symphonic poems:

\section{Illustration $\mathbf{5}^{15}$}

\begin{tabular}{|c|c|c|c|}
\hline \multicolumn{4}{|c|}{ Thematic transformation in Fibich's symphonic poem Záboj, Slavoj a Luděk } \\
\hline Theme & Description of theme & Page- and bar-numbers & Tempo, key, metre \\
\hline \multirow[t]{6}{*}{ Záboj's theme } & unaccompanied solo & p. 4, b. 27 & Sostenuto, a, 2/4 \\
\hline & $\begin{array}{c}\text { imitated } \\
\text { at } 2 \text { bars' distance }\end{array}$ & p. 5, b.41 & Sostenuto, a, 2/4 \\
\hline & $\begin{array}{l}1^{\text {st }} 5 \text { notes imitated } \\
\text { at } 1 \text { bar's distance }\end{array}$ & p. 27, b. 218 & Quasi presto, F, C \\
\hline & fully harmonised & p. 37, b.289 & Largamente, $\mathrm{f}, \mathrm{C}$ \\
\hline & with new $1^{\text {st }}$ beat & p. 44, b. 325 & $\begin{array}{c}\text { Energico (poco meno } \\
\text { mosso), } D, 2 / 4\end{array}$ \\
\hline & with new continuation & p. 96, b. 566 & Poco vivo, $A, C$ \\
\hline
\end{tabular}

He also consciously develops his thematic material by transferring it from its original register to alternative tessituras, as is demonstrated by Illustration 6 . $\mathrm{He}$ is more systematic than his predecessors in his application of this technique:

15 The score used is as follows: Fibich: Záboj, Slavoj a Luděk op. 37 (Prague: Státní Hudební Vydavatelství, 1962). 
Illustration $6^{16}$

\begin{tabular}{|c|c|c|c|}
\hline \multicolumn{4}{|c|}{ Changes of register in Fibich's symphonic poem Toman a lesní panna } \\
\hline Theme & Page- and bar-numbers & Tempo, key, metre & Register \\
\hline $2^{\text {nd }}$ theme & p. 7, b.41 & Poco più vivace, A, 2/4 & Tenor \\
\hline & p. 18, b.103 & Allegro, G, 2/4 & Bass \\
\hline & p. 68, b.365 & Più lento, Eb, 2/4 & $\begin{array}{c}\text { Soprano, doubled at the } \\
\text { 8ve and 15 } 5^{\text {th }} \text { below }\end{array}$ \\
\hline $4^{\text {th }}$ theme & p. 48, b.278 & $\begin{array}{c}\text { Allegro vivace e leggiero, } \\
\text { d, 3/4 }\end{array}$ & Soprano \\
\hline & p. 62, b.345 & Più lento, a, 3/4 & Tenor \\
\hline & p. 87, b.439 & Andantino, d, 3/4 & $\begin{array}{c}\text { Variant in bass, doubled } \\
\text { at the 8ve above }\end{array}$ \\
\hline
\end{tabular}

One particular harmonic detail seems to have percolated from Liszt through Smetana and down to Fibich, i.e. the beginning of a thematic statement on a 6-4 (second-inversion) chord. Instances are detailed in Illustration 7. The example in Bouře enriches the harmony to a 6-4-3, while the first entry under Vesna breaks new ground in its use of an augmented (rather than major or minor) triad:

\section{Illustration $7^{17}$}

\begin{tabular}{|c|c|c|}
\hline \multicolumn{3}{|c|}{ Examples of themes beginning on a 6-4 (second-inversion) chord } \\
\hline Work & Location of theme and chord & Original location of theme and chord \\
\hline Les préludes & p. 44, b.192 (G:6-4) & p. 14, b.47 (C:5-3) \\
\hline & & p. 45, b.201 (E:6-4) \\
\hline Mazeppa & p. 69, b.370 (C:6-4) & p. 17, b.70 (E:5-3) \\
\hline Festklänge & p. 114, b.579 (F:6-4) & p. 36, b.122 (bb:5-3) \\
\hline Die ldeale & & p. 1, b.5 (C:6-4) \\
\hline Blaník & p. 463, b.230 (F:6-4) & pábor, p. 348,198 (D:6-4) b.98 (F:5-3) \\
\hline Toman a lesni panna & & p. 7, b.41 (A:6-4) \\
\hline & & p. 21, b.123 (Eb:6-4) \\
\hline & & p. 68, b.365 (Eb:6-4) \\
\hline & & p. 26, b.141 (Bb:6-4) \\
\hline
\end{tabular}

${ }_{16}$ The score used is as follows: Fibich: Toman a lesni panna op.49 (Prague: SNKLHU, 1959).

17 The scores used are as follows: Liszt: Les préludes (London: Eulenburg, 1977), Liszt: Mazeppa (London: Eulenburg, n.d.), Liszt: Festklänge (as note 5), Liszt: Die Ideale (London: Eulenburg, n.d.), Smetana: Má vlast (Prague: Editio Supraphon, 1987), Fibich: Toman a lesnípanna (as note 16), Fibich: Bouře op.46 (Prague: Státní Hudební Vydavatelství, 1961) and Fibich: Vesna op. 13 (Prague: SNKLHU, 1961). 


\begin{tabular}{|c|c|c|}
\hline \multicolumn{3}{|c|}{ Examples of themes beginning on a 6-4 (second-inversion) chord } \\
\hline Work & Location of theme and chord & Original location of theme and chord \\
\hline & p. 87, b.439 (d:6-4) & p. 48, b.278 (d:5-3) \\
\hline Bouře & & p. 53, b.287 (Bb:6-4-3) \\
\hline Vesna & p. 17, b.87 (E aug. triad:6-4) & p.1, b.1 (A: no harmony) \\
\hline & p. 22, b.132 (C:5-3)! & p. 19, b.111 (C:6-4) \\
\hline & p. 40, b.229 (F:6-4) & p. 1, b.1 (A: no harmony) \\
\hline
\end{tabular}

In his symphonic poems Fibich avoids the kind of fugal writing that Liszt resorted to in Prometheus, Hunnenschlacht and Die Ideale, and that Smetana worked out in $Z$ českých luhĩ a hájü ${ }^{18}$. However, his first work in the genre, Othello, presents his credentials as a contrapuntist in two passages which briefly feature canonic imitation $^{19}$ and one imitative entry where the trailing voice is a retrograde version of the leading voice (a variant of Desdemona's theme) ${ }^{20}$.

In a number of these pieces the ending is approached by a passage of calm serenity which is typically characterized by sustained or tremolando strings, sustained woodwind and brass, and harp arpeggios. The passage may be accompanied by a descriptive title such as "maestoso" or "andante religioso". Liszt briefly introduced the idea in his first symphonic poem, Ce quion entend sur la montagne ${ }^{21}$, and Smetana followed suit in Richard III and especially in Hakon Jar ${ }^{22}$. Fibich recalled these works with similar examples in Záboj, Slavoj a Luděk and Toman a lesnipanna, the first of these being a particularly effective representative ${ }^{23}$.

As the design of the symphonic poem is not bound by the restrictions of sonata form, it offers the composer an unlimited freedom to explore the fullest possible tonal colours, and Liszt avails of this opportunity, especially in three works which possess a range of keys from six flats at one end to seven sharps at the other ${ }^{24}$. In Hakon Jarl Smetana goes one step further with the complete

18 See respectively Liszt: Prometheus (London: Eulenburg, n.d.), p. 27, bar 159; Liszt: Hunnenschlacht (London: Eulenburg, n.d.), p. 53, bar 219; Liszt: Die Ideale (as note 17), p. 77, bar 569; and Smetana: Má vlast (as note 17), $Z$ českých luhĩ a hájů, p. 258, bar 74.

19 See Fibich: Othello (as note 7), pp. 21-22, bars 111-114 and pp. 46-49, bars 251-264.

${ }^{20}$ See Fibich: Othello (as note 7), p. 53, bars 313-314, where the notes F-D-C\# are imitated by $\mathrm{F}-\mathrm{Gb}-\mathrm{Bb}$.

${ }^{21}$ See Lisz: Ce quion entend sur la montagne (Leipzig: Breitkopf und Härtel, 1907), pp. 157-158 (no bar-numbers provided).

22 See Smetana: Richard III - Valdštýnưv tabor - Hakon Jarl (Prague: Společnost Bedřicha Smetany, 1942), Richard III, p. 66, bars 312-319 and Hakon Jarl, pp. 218-226, bars 362-387.

${ }^{23}$ See Fibich: Záboj, Slavoj a Luděk (as note 15), pp. 86-93, bars 532-551, and Fibich: Toman a lesni panna (as note 16), pp. 85-86, bars 432-438.

${ }_{24}$ These works are Ce quion entend sur la montagne, Tasso and Festklänge. 
spectrum, from A flat minor to C sharp major ${ }^{25}$. Fibich is more modest, and in both major-key works, i.e. Othello and Vesna, he completely avoids the mediant and leading-note as tonal centres. His one novelty occurs in Vesna, where the music briefly visits $\mathrm{D}$ flat major, a distance from the tonic $\mathrm{A}$ major not used by either of his predecessors in their major-key pieces ${ }^{26}$.

While the symphonic poems of all three composers inevitably share structural features, Fibich essentially approaches this aspect with an independent mindset. One need only to think of the opening two themes in Othello, which are heard several times in the first $20 \%$ (i.e. 96 bars) and then no more in the remaining $80 \%$ of the work (i.e. 387 bars). Similarly the conventional recapitulation of Desdemona's theme in the tonic key, $\mathrm{D}$, proves to be abortive ${ }^{27}$. The works usually subscribe to a tripartite plan, but with clear variations from one composition to the next. While the first three main themes in Záboj, Slavoj a Ludék are introduced in $\mathrm{A}$ minor ${ }^{28}$, the opposite strategy is employed in Toman a lesni panna, where the first three main themes are presented in $\mathrm{D}$ minor, $\mathrm{A}$ major and $\mathrm{B}$ flat major respectively ${ }^{29}$. In fact the key-scheme underpinning the structure of the latter work consists of a sequence of symmetrical blocks which may be seen in Illustration 8:

\section{Illustration 8}

\begin{tabular}{|c|c|c|c|}
\hline \multicolumn{5}{|c|}{ Key-scheme in Toman a lesni panna } \\
\hline Theme & Page & Bar & Comment \\
\hline A & 1 & 1 & \\
\hline B & 7 & 41 & ABA symmetry \\
\hline A & 14 & 82 & \\
\hline B & 18 & 103 & \\
\hline C & 26 & 141 & BCB symmetry \\
\hline B & 30 & 172 & \\
\hline A & 43 & 245 & \\
\hline D & 48 & 278 & \\
\hline B & 68 & 365 & \\
\hline D & 75 & 395 & \\
\hline B & 76 & 399 & \\
\hline
\end{tabular}

${ }_{25}$ See Smetana: Richard III - Valdštýnưv tabor - Hakon Jarl (as note 22), Hakon Jarl, p. 185, bars 151-156 (A flat minor) and pp. 224-225, bars 382-383 (C sharp major).

${ }_{26}$ See Fibich: Vesna (as note 17), pp. 61-62, bars 365-369.

27 See Fibich: Othello (as note 7), pp. 43-44, bars /231-232.

${ }_{28}$ See Fibich: Záboj, Slavoj a Ludék (as note 15), p. 1, bar /2, p. 2, bar 7 and p. 4, bar 27.

${ }_{29}$ See Fibich: Toman a lesni panna (as note 16), p. 1, bar 1, p. 7, bar 41 and p. 26, bar 141. 


\begin{tabular}{|c|c|c|c|}
\hline \multicolumn{5}{|c|}{ Key-scheme in Toman a lesni panna } \\
\hline Theme & Page & Bar & Comment \\
\hline D & 87 & 439 & \\
\hline A & 89 & 456 & ADBDBDA symmetry \\
\hline
\end{tabular}

Othello is similarly designed with an arc-shaped ABCBA sequence of principal tonal regions, as summarized in Illustration 9:

\section{Illustration 9}

\begin{tabular}{|c|c|c|}
\hline \multicolumn{3}{|c|}{ Principal tonal regions in Othello } \\
\hline Key & Page & Bar \\
\hline D & 1 & 1 \\
\hline Bb & 20 & 249 \\
\hline d & 46 & $/ 438$ \\
\hline Bb & 69 & 474 \\
\hline D & 75 & \\
\hline
\end{tabular}

By contrast Boure is rich in variants, with no less than five closely related melodic ideas in the first thematic group ${ }^{30}$ and three related ideas in the second thematic group ${ }^{31}$. Taking his cue from Smetana, especially in the three Swedish symphonic poems, Fibich incorporates new material into the development of the main themes in three of his five works, i.e. Záboj, Slavoj a Luděk, Toman a lesní panna and Vesna ${ }^{32}$.

For works which demonstrate a high quality of craftsmanship and contain much attractive content, Fibich's symphonic poems have over the years suffered an almost complete neglect in both concert hall and studio recording. It is to be hoped that the fact that Naxos has recently issued its five-CD set of the composer's complete orchestral works may indicate the awakening of a new interest in this corpus of music.

${ }^{30}$ See Fibich: Boure (as note 17), p. 1, bar 3, p. 5, bar 23, p. 8, bar 40, p. 14, bar 68 and p. 17, bar 80.

31 See Fibich: Bouře (as note 17), p. 21, bar 101, p. 21, bar 113 and p. 22, bar 121.

32 See respectively Fibich: Záboj, Slavoj a Ludèk (as note 15), pp. 55-58, bars 376-390; Fibich: Toman a lesni panna (as note 16), pp. 45-47, bars 256-277; and Fibich: Vesna (as note 17), pp. 53-58, bars 297-340. 


\section{Considerations of Inheritance in Zdeněk Fibich's Symphonic Poems}

\section{Abstract}

Dictionary entries on the symphonic poem place the Czech Lands ahead of Russia, France, Germany and other countries. This sequence highlights the important pioneering attempts of a number of composers in Bohemia and Moravia who contributed vitally to the evolution of a form which was barely out of its infancy. Although the Czech symphony had witnessed no significant representative work for some fifty years since Jan Václav Vořišek's Symphony in D of 1821 - both Bedřich Smetana and Antonín Dvořák had continued in the central European symphonic tradition without any appreciable breakthrough or impact - Smetana's three "Swedish" symphonic poems of 1858-1861 achieved a certain notoriety and today stand as early landmarks in the history of the genre. Fibich would have been aware of the compositions of both Franz Liszt and Smetana when he turned to the fledgling form in 1873 with the first two of his works, Othello and Záboj, Slavoj a Luděk [Záboj, Slavoj and Luděk]; the other three pieces, Toman a lesni panna [Toman and the Wood Nymph], Bouř [The Tempest] and Vesna [Spring], followed in the next eight years. While this makes the collection contemporary with Smetana's cycle Má vlast, the question of inheritance is more appropriately applied to the Liszt and earlier Smetana series. The far-reaching influence of sonata form as handled by all three composers represents one of several avenues of inquiry in order to identify which aspects of the structure Fibich imitated in his music and which emerge as unconventional or original features.

\section{Úvahy nad odkazem v symfonických básních Zdeňka Fibicha}

\section{Abstrakt}

Hesla ve slovnících pod termínem symfonická báseň umistují české země před Rusko, Francii, Německo a jiné státy. Toto pořadí vyzdvihuje důležitost pionýrských pokusů několika skladatelů v Čechách a na Moravě, kteří podstatně př̀ispěli k vývoji formy, jež sotva opustila svou nejranější fázi. Ačkoliv česká symfonie nezaznamenala výraznější reprezentativní skladby po dobu téměř padesáti let od dob Symfonie D dur Jana Václava Vořiška z roku 1821 - Bedřich Smetana i Antonín Dvořák pokračovali ve středoevropské tradici komponování symfonických děl bez jakýchkoliv výrazných inovací a uznání - Smetanovy tři „švédské“ symfonické básně z let 1858-1861 dosáhly jisté proslulosti a dnes stojí jako rané mezníky v historii tohoto žánru. Fibich znal kompozice Franze Liszta a Smetany ve chvíli, kdy se v roce 1873 přiklonil k rodící se formě svými prvními dvěma kompozicemi Othello a Záboj, Slavoj a Luděk; ostatní tři skladby Toman a lesní 
panna, Bouře a Vesna vznikly v následujících osmi letech. Ačkoliv byly tyto skladby vytvořeny ve stejné době jako Smetanův cyklus Má vlast, mají daleko blíže k Lisztovým a ranějším Smetanovým symfonickým básním. Dalekosáhlý vliv sonátové formy zpracovaný všemi třemi skladateli reprezentuje jednu z několika cest výzkumu ve snaze rozpoznat, které aspekty kompoziční struktury Fibich imitoval ve své hudbě a které vznikly jako nekonvenční nebo originální pojetí skladatele.

\section{Keywords}

Czech music; Zdeněk Fibich; symphonic poem

\section{Klíčová slova}

česká hudba; Zdeněk Fibich; symfonická báseň

Patrick F. Devine

Patrick.Devine@mu.ie 